\title{
CSR Expenditure and Company Performance: Charity or Signal? Evidence from Indonesia
}

DOI: 10.12776/QIP.V23I3.1273

Erna Widiastuty, Noorlailie Soewarno

Received: 24 June 2019 Accepted: 05 October 2019 Published: 30 November 2019

\begin{abstract}
Purpose: The purpose of this study are: first, to investigate CSR expenditures made by public companies in Indonesia are whether aimed at the charity, and second, whether CSR expenditure is related to the corporate's performance in the future.

Methodology/Approach: The samples are taken from 53 companies registered at the Indonesia Stock Exchange. Measurement of CSR expenditure uses monetary unit because CSR expenditure is the actual expenditure of the company. Company performance variables use ROA and CFO.

Findings: The result indicates that CSR expenditures by companies in Indonesia are aimed at charity and are not related to their future performance. In addition, the CFO is also not related to CSR expenditure. This finding indicates that the expenditure of corporate CSR in Indonesia is only limited to fulfilling corporate social responsibility to the community without expecting repayment and to fulfill applicable regulatory obligations. Thus the resulting decision is a charity decision, not a signal.
\end{abstract}

Research Limitation/implication: Sample in this study is limited to only company that reports CSR expenditure data in its annual report. The problem is that this disclosure is not mandatory in Indonesia so we cannot put all of public companies into our study. Our findings must be interpreted with this sample limitation problem.

Originality/Value of paper: Our study contributes to understanding of motives of corporation in CSR spending. Corporations that operate in Indonesia are not only local corporations. Some are foreign companies that operate in Indonesia. Even though this Indonesian-based foreign corporation has its CSR program running in Indonesia, the program actually made by its home office abroad. 
While the CSR activity is used as signal in the home country, the purpose is not the same in Indonesia.

Category: Research paper

Keywords: CSR expenditures; signaling theory; charity; company performance; Indonesia

\section{INTRODUCTION}

The debates whether CSR activities conducted by corporates related to philanthropy (charity) or reflecting corporate performance (signals) in the future are still not reaching inclusive conclusions until now (Lev, Petrovits and Radhakrishnan, 2010; Hong, Kubik and Scheinkman, 2012; Nollet, Filis and Mitrokostas, 2016; Bose, Podder and Biswa, 2017; Danielli, Bini and Giunta, 2013; Lys, Naughton and Wang, 2015; Chen, Feldman and Tang, 2015; Rhou, Singal and Koh, 2016; Supriyadi and Tjahjadi, 2017). Neoclassical economists like Friedman (1970); Galaskiewicz (1991); Brammer and Millington (2008) are parties that do not support CSR activities. Meanwhile, Fombrun (2005); Hoopwood (2009); Brammer, Brooks and Pavalin (2006); Weber et al. (2008) are parties that support CSR activities. Friedman (1970), Galaskiewicz (1991), Brammer and Millington (2008)'s preference to not supporting CSR activities incurred by corporates is caused by the argument that, based on their functions, managers are those who are responsible for increasing the prosperity of shareholders, not running CSR activities that are supposed to run by the government.

Shifting from those who do not support, Fombrun (2005), Brammer, Brooks and Pavalin (2006), Weber et al. (2008), Hoopwood (2009) stated that there is a positive relationship between CSR activities and corporate performance. According to them, if the corporate increases its CSR activities then reports on such, the actions taken can improve the corporate's image as part of good citizenship. This will attract investors and increase the legitimacy of the corporate (Bowen, 1953; Servaes and Tamayo, 2013) and certainly have an impact on improving corporate performance in the future (signal) (Danielli, Bini and Giunta, 2013; Lys, Naughton and Wang, 2015; Rhou, Singal and Koh, 2016; Wang and Sarkis, 2017; Esteban-Sanchez, De la Cuesta-Gonzalez and ParedesGazquez, 2017).

In our opinion, CSR activities conducted by the corporate should not only as a signal-oriented towards material benefits but also aim to take part in thinking about the welfare of society and the environment (charity). This result is in accordance with the study conducted by Chapple and Moon (2005). They concluded that there were variations in disclosure of the corporate's CSR activities through the web between corporates in Asian countries. However, these variations failed to be explained by the stages of state development. Factors of globalization increase the adoption of CSR activities in Asian countries, yet 
multinational corporates operating in Asia tend to adopt CSR activities where countries of origin operate instead of adjusting to the conditions of the country where they invest. In addition, their research findings show that in developing countries, especially Asia, CSR activities conducted by corporates are focused on charities.

Our study was motivated by a study by Danielli, Bini and Giunta (2013) and Lys, Naughton and Wang (2015). In this case, CSR expenditures referred to in our study are monetary expenditures incurred by corporates to finance CSR activities. This is consistent with the study conducted by Lys, Naughton and Wang (2015). According to them, the purpose of CSR expenditures in the beginning was to perform social actions. In this case, the corporate wants to be useful in the eyes of the community (charity). Whereas, the corporate actions to conduct CSR activities in the form of CSR expenditures are considered to be aimed at giving a signal about the corporate's future prospects (signals). To differentiate between hypotheses aimed at charity and aimed at signals, the charity hypothesis is not related to improving future performance. The improvement in corporate performance in the future is actually a management expectation and not a result of the corporate's CSR expenditures in the previous period. Conversely, the signal hypothesis, when the corporate's CSR activities in the form of CSR expenditures made by the corporate today, is a signal about the corporate performance in the future.

Our study was conducted at manufacturing corporates listed on the Indonesia Stock Exchange. In the context of developing countries, the difficulties arise in the generalization of study findings regarding CSR activities incurred by the corporates. Moreover, the limitations of the sample and the scope of the data, and then the socio-cultural and institutional differences between developed countries and developing countries according to Cai, Pan and Statman (2016), Bose, Podder and Biswas (2017) are the cause of that difficulties. Furthermore, our study aims to expand the existing literature by examining economic problems that occur in developing countries. Indonesia is a developing country as a part of the G-20 Forum membership which indicates that Indonesia is one of twenty countries with the largest economy in the world. The Indonesian capital market is one of the increasing Asian capital markets currently attracting global investment from various parts of the world (Darmadi, 2013). Since 2007, The Government of Indonesia has issued regulations regarding CSR activities of corporates through the Law on Public Corporates No. 40/2007. The regulation oversees the mandatory disclosure and reporting of CSR activities by public corporates.

According to Griffin and Prakash (2014), it is very important for corporates to choose and then decide on CSR initiatives and emphasize those choices, then combine them to stakeholder-oriented activities with an issue. This has an impact on differences in stakeholder expectations regarding prospects and evaluation of the results of CSR activities as a measurement of corporate performance (Wang et al., 2016). This study provide evidance First, CSR expenditures by Indonesia corporations have charity motive. Second, there is a correlation between CSR 
expenditure and corporate performance and information about CSR expenditures delivered by the corporate is a signal to outsiders that the corporate is growing. The measurement of CSR expenditure in this study uses monetary units, as used by Lys, Naughton and Wang (2015). We estimate the assumption that the costs and benefits of CSR activities through monetary expenditures incurred by corporates are difficult to be convincingly identified, whereas the corporate's goal of disclosing more information (including CSR expenditures) is to reduce information asymmetry so that investors can assess them better (Healy and Palepu, 2000; Lech, 2012; Danielli, Bini and Giunta, 2013; Lys, Naughton and Wang, 2015; Zhang, 2016).

\section{LITERATURE REVIEW AND DEVELOPMENT OF HYPOTESES}

In the USA, charitable contributions through CSR expenditures indicated by data from the Committee on Encouraging Corporate Philanthropy (2008), on average, were experiencing an increase of 5.6\% in 2007. Even as quoted from Lev, Petrovits and Radhakrishnan (2010) as many as seven of the eight corporates they studied which reported losses over two decades, still had increased their charitable distribution through CSR activities. Another study by Hong, Kubik and Scheinkman (2012) concluded that corporates having excess cash flow will take the initiative to act on CSR expenditures. This action is similar to corporates doing charity which means, the initiative of monetary expenditures in the form of CSR activities is due to excess resources and then does so without expecting that the CSR expenditures will have an impact on corporate performance (Navarro, 1988; Humphrey, Lee and Shen, 2012).

Stakeholder theory explains how organizations respond to various requests from stakeholders. Based on the perspective of the theory, it is very important for corporates to achieve competitive advantages in order to ensure the sustainability of the corporation in society. CSR activity in the form of charity is one of the activities which aims as a form of the corporate's response to social demands. In addition, charitable giving through CSR activities by corporates can build the corporate's reputation in society (Aly, El-Halaby and Hussainey, 2018).

Lev, Petrovits and Radhakrishnan (2010), Nollet, Filis and Mitrokostas (2016), Bose, Podder and Biswas (2017) conducted studies on CSR activities in the form of charitable giving. Lev, Petrovits and Radhakrishnan (2010) examined the impact of corporate philanthropic activities on sales growth. In this case, there is a growth in sales by public corporates in the USA which contribute in the form of charity. Using the Granger causality test, their findings suggest that corporates contributing to charitable activities are significantly associated with increased revenues in the future. In addition, they show that increasing revenues occur only at corporates that care about consumer perceptions and assume those consumers as their importance. Moreover, their findings also document a positive relationship between the corporate's contribution to charity and customer 
satisfaction. This indicates that philanthropy conducted by the corporate under certain circumstances will increase the corporate's revenue.

Bose, Podder and Biswas (2017) investigated the relationship between CSR activities in the form of charitable giving by corporates with market-based performance and institutional ownership. Using samples from banking in Bangladesh, their findings exhibited banking corporates with CSR activities through higher charity had better performance. In addition, CSR activities through charity are positively related to institutional ownership. This certainly implies that institutional owners contribute more to CSR activities through charity. This finding is certainly interesting for managers, regulators, and policymakers in countries that have similar economic and social systems.

Nollen, Filis and Mitrokostas (2016) were motivated to test the linear and nonlinear correlation between CSP and CFP (accounting and market-based) using a new set of disclosure scores data from Bloomberg's Social Governance which include S\&P 500 corporates. The linear correlation shows a negative and significant direction for CSP, however, non-linear models provide the opposite result between CSP and CFP. Bose Bose, Podder and Biswas (2017) pointed that, from a stakeholder theory perspective, there is a linear correlation between charitable contributions to the performance of market-based corporates and institutional investors are reacting positively to the corporate's charitable contributions based on sample of 137 financial corporates, namely the banking industry in Bangladesh for the period of 2007-2013.

Other evidence related to the charity hypothesis, for example, according to Lys, Naughton and Wang (2015), corporates do spend CSR expenditures on ineffective activities. As the aim is to "beautify" the manager's performance and to achieve this goal, the manager will invest in his or her preferred CSR activities acting on behalf of stakeholders by carrying out CSR expenditures in the amount he or she agreed to (Bénabou and Tirole, 2010). Based on the empirical evidence above that the corporate's CSR activities done through CSR expenditures can be functioned as a charity, we propose the following hypothesis:

Hal:The corporate's current CSR expenditures are not related to the corporate's performance in the future (charity hypothesis).

The connection between CSR expenditures and corporate performance can be explained through signaling theory. According to this theory, there is a condition where information asymmetry between the corporate and other parties outside the corporate occurred. Differences in information will set parties outside the corporate to look for information (signals) that distinguishes between good and bad performing corporates. Under these conditions, the more information reported by the corporate, the more improvement corporate can perform in the future (Healy and Palepu, 2000; Lech, 2012; Danielli, Bini and Giunta, 2013; Lys, Naughton and Wang,2015). The use of information about CSR expenditures is an appropriate guide for examining the components of corporate CSR activities (Hilman and Keim, 2001; Caroll, 2004; Choi and Wang, 2007). The corporate's 
decision to engage in CSR activities is related to corporate's signals (Mahoney et al., 2013).

Some results from previous researches reveal evidence that CSR activities are related to corporate performance in the future (Danielli, Bini and Giunta, 2013; Lys, Naughton and Wang, 2015; Chen, Feldman and Tang, 2015; Rhou, Singal and Koh, 2016; Supriyadi and Tjahjadi, 2017). For instance, research conducted by Danielli, Bini and Giunta (2013) aims to determine whether incremental information in CSR reports and annual financial statements disclosed by the corporate is a signaling strategy related to corporate performance. They suspect that the disclosure indicators in the annual report provide additional information related to corporate performance, which in this case, profitability. The corporates sampled in this study were 120 corporates in Italy. Their research results confirm that the number of CSR information indicators reported by the corporate is positively related to the profitability of the corporate.

Lys, Naughton and Wang (2015) examine the relationship between corporate expenditure on social responsibility and corporate performance. They assume that spending on corporate social responsibility is not a form of corporate charity and is also not related to improving financial performance in the future. Their research shows that there is a causal relationship that has a positive value between CSR expenditure and corporate performance in the future.

A study conducted by Rhou, Singal and Koh (2016) investigate the role of CSR awareness measured through CSR activities covered by the media to moderate the relationship between social responsibility (CSR) and corporate financial performance (CFP) in the context of restaurant industry corporates. They invetigate whether CSR awareness moderates the relationship between social and financial performance. The results of their study support the idea that CSR awareness of stakeholders will influence CSR initiatives and relate to increasing corporate finance only if corporates effectively publish their CSR involvement. In short, they highlight the importance of increasing positive CSR awareness through increasing media space for socially responsible corporate activities. In addition, it also shows the importance of managing negative CSR awareness as an effort of the corporate to avoid the bad relationship between the corporate and its main stakeholders.

The corporate will voluntarily disclose information that aims to reduce the asymmetry of information between corporate management and stakeholders as a form of corporate communication. Signaling is an extension of voluntary disclosure carried out by the corporate. Signaling theory shows that corporates, in this regard as "good" citizens, convey separate CSR information and are reported independently which shows a signal of their superior commitment to CSR activities (Mahoney et al., 2013). The corporate expects that their actions aside from reducing the asymmetry of information, also to benefit from their signaling actions through CSR (Ching and Gerab, 2017). External stakeholders who are 
interested in the information released by the corporate will look for additional information.

The signal hypothesis does not require the corporate to actively express its future prospects when making certain investments and CSR activities. On the contrary, it only requires that corporate CSR expenditures "gives the signal" about the corporate's future financial prospects. This definition of signaling is consistent with several studies of dividends, where the changes in dividend have implications for the corporate's future cash flows even though there is no intention from the corporate to convey information about future performance (Miller and Rock, 1985; John and Williams, 1985). So, it can be concluded that CSR expenditures made by corporates are thought to be related to the corporate's performance in the future.

The benefits obtained through CSR activities which include increasing the positive image of the corporate (Brammer and Miliington, 2008; Kreander, Beattie and McPhail, 2009), attracting shareholders (Wang and Qian, 2011) for example, because of CSR issues related to employee safety at mining corporates (Wang and Sarkis, 2017; Esteban-Sanchez, De la Cuesta-Gonzalez and ParedesGazquez, 2017; Christensen et al., 2017) and are expected to increase the corporate's cost of capital (El Ghoul et al., 2011). To attract interest to the market, information containing signals according to Beyer et al. (2010) have two characteristics. First, relevant if used as the basis for decision making. Second, if information comes from management, the information is considered private. Based on the explanation above, we propose the following hypothesis:

Ha2: The corporate's current CSR expenditures are related to corporate's performance in the future (signal hypothesis).

\section{METHODOLOGY}

\subsection{Data Collection Procedure}

Information related to CSR expenditures (in Indonesian Rupiah) is obtained through the corporate's annual report for the period of 2012-2016. We follow measurement used by Servaes and Tamayo (2013) and Lys, Naughton and Wang (2015).

Our research samples are manufacturing corporates listed on the Indonesia Stock Exchange. We use the manufacturing data because their operations have direct impacts on societies and the environment. This is consistent with the study conducted by Testa and D'Amato (2017). Corporate performance is proxied by viewing at the total return on assets (ROA) since it describes the level of management effectiveness in generating profit using existing corporate assets. Changes in future performance in this study are measured by $\triangle \mathrm{ROAi}_{\mathrm{t}+1}$. Future changes in operating cash flow is cash flow operation (CFO) scaled to total 
assets. Lys, Naughton and Wang (2015) argue that CFO have a better persistence level and are considered more difficult to manipulate.

\subsection{Research Model}

The analysis is conducted by testing whether there is a positive connection between current CSR expenditures and future corporate performance. These measurements observe changes in return on assets and operating cash flows. Different from Lys, Naughton and Wang (2015), this study does not separate economic and non- economic based CSR components. Hypotheses are tested as follows:

$$
\begin{aligned}
& \Delta \mathrm{ROAi}_{, \mathrm{tt}+1}=\alpha_{0 \mathrm{a}}+\alpha_{1 \mathrm{a}} \mathrm{CSR}_{\operatorname{Exp}_{\mathrm{it}}}+\alpha_{2 \mathrm{a}} \Delta \mathrm{ROA}_{\mathrm{it}}+\alpha_{3 \mathrm{a}} \Delta \mathrm{ROA}_{\mathrm{i}, \mathrm{t}+1}+\varepsilon_{1 \mathrm{a}} \\
& \Delta \mathrm{CFO}_{\mathrm{i}, \mathrm{t}+1}=\beta_{0 \mathrm{a}}+\beta_{1 \mathrm{a}} \mathrm{CSR}_{-} \operatorname{Exp}_{\mathrm{i}}+\beta_{2 \mathrm{a}} \Delta \mathrm{CFO}_{\mathrm{it}}+\beta_{3 \mathrm{a}} \Delta \mathrm{CFO}_{\mathrm{it}-1}+\varepsilon_{1 \mathrm{a}}
\end{aligned}
$$

Where, $\triangle \mathrm{ROAi}_{\mathrm{t}+1}$ are changes in company i performance in the future, CSR_Exp $\mathrm{it}_{\mathrm{it}}$ is corporate $i$ 's CSR expenditure in the year $t, \mathrm{ROA}_{\mathrm{it}}$ are changes in company $i$ 's performance in the year $t$ and $\Delta \mathrm{CFO}_{\mathrm{i}, \mathrm{t}+1}$ are changes in future cash flows of company $i$ in the year $t+1$.

\section{RESULT AND DISCUSSION}

\subsection{Descriptive Statistics Analysis}

Tab. 1 presents descriptive statistics of the regression results from (1) and (2). There are several interesting points from the two regression results. First, the minimum value of CSR expenditure is 0.00 . This value of 0 cannot be interpreted that there was no CSR expenditure in that year. We can only conclude that the company did not disclose its expenditure value in the year of observation.

\begin{tabular}{|c|c|c|c|c|c|}
\hline Information & Variables & Minimum & Maximum & Mean & Std. Deviation \\
\hline \multirow[t]{4}{*}{ Eq.1 } & $\Delta \mathrm{ROA}_{\mathrm{i}, t+1}$ & -0.465 & 0.467 & -0.002 & 0.084 \\
\hline & CSR_Exp $p_{i, t}$ & 0.000 & 0.984 & 0.061 & 0.154 \\
\hline & $\Delta \mathrm{ROA}_{\mathrm{i}, \mathrm{t}}$ & -0.214 & 0.511 & 0.044 & 0.083 \\
\hline & $\mathrm{ROA}_{\mathrm{i}, \mathrm{t}-1}$ & -0.662 & 0.511 & 0.046 & 0.098 \\
\hline \multirow[t]{4}{*}{$E q .2$} & $\Delta \mathrm{CFO}_{\mathrm{i}, \mathrm{t}+1}$ & -1.118 & 2.710 & -0.001 & 0.244 \\
\hline & CSR_Exp $p_{i, t}$ & 0.000 & 0.984 & 0.061 & 0.154 \\
\hline & $\Delta \mathrm{CFO}_{\mathrm{i}, \mathrm{t}}$ & -0.582 & 2.722 & 0.067 & 0.209 \\
\hline & $\mathrm{CFO}_{\mathrm{i}, \mathrm{t}-1}$ & -0.582 & 1.255 & 0.068 & 0.151 \\
\hline
\end{tabular}

Table 1 - Descriptive Statistics 
Another interesting result is that the minimum value of ROA is negative. This is because a sample of companies that report losses is included. On the other hand, the maximum value of ROA is quite high i.e. 0.51 while the mean is 0.05 . So there is a fairly wide range between the lowest value and the highest value. We can also draw the same conclusion for the CFO data in (2).

\subsection{Hypotheses Test}

Tab. 2 presents the regression results between variables from the tested hypothesis.

Table 2 - Regression Result

\begin{tabular}{|c|c|c|c|c|c|c|c|c|}
\hline Var & \begin{tabular}{|c|} 
Constant \\
Eq 1
\end{tabular} & $\begin{array}{c}\text { Constant } \\
\text { Eq } 2\end{array}$ & $\begin{array}{c}\mathrm{CSR}_{-} \\
\operatorname{Exp}_{\mathrm{i}, \mathrm{t}} \\
\operatorname{Eq}_{1}\end{array}$ & $\begin{array}{c}\operatorname{CSR}_{-} \\
\operatorname{Exp}_{\mathrm{i}, \mathrm{t}} \\
\operatorname{Eq}_{2}\end{array}$ & $\Delta \mathbf{R O} \mathbf{A}_{i, t}$ & $\mathbf{R O A}_{i, t-1}$ & $\Delta \mathbf{C F O}_{\mathrm{i}, \mathrm{t}}$ & $\mathrm{CFO}_{\mathrm{i}, \mathrm{t}-1}$ \\
\hline $\begin{array}{l}\text { Reg } \\
\text { Eq. } 1\end{array}$ & $\begin{array}{r}-0.001 \\
(0.852)\end{array}$ & -- & $\begin{array}{r}0.000 \\
(0.663)\end{array}$ & -- & $\begin{array}{r}0.759 \\
(0.000)\end{array}$ & $\begin{array}{r}0.090 \\
(0.084)\end{array}$ & -- & -- \\
\hline $\begin{array}{l}\text { Reg } \\
\text { Eq. } 2\end{array}$ & -- & $\begin{array}{r}0.043 \\
(0.001)\end{array}$ & -- & $\begin{array}{r}0.000 \\
(0.755)\end{array}$ & -- & -- & $\begin{array}{r}-0.037 \\
(0.619)\end{array}$ & $\begin{array}{r}-0.942 \\
(0.000)\end{array}$ \\
\hline Eq. 1 & $\mathrm{R}^{2}: 46 \%$ & \multicolumn{2}{|c|}{ F-value: 89.332} & \multicolumn{2}{|c|}{ p-value: 0.000} & & & \\
\hline Eq. 2 & $\mathrm{R}^{2}: 52 \%$ & \multicolumn{2}{|c|}{ F-value: 114.501} & \multicolumn{2}{|c|}{ p-value: 0.000} & & & \\
\hline
\end{tabular}

Notes: ROA (return on asset) is return on asset measured by the ratio of net income to net assets; CSR_Exp (corporate social responsibility expenditure) is corporate social responsibility expenditure measured by the amount of expenditure in Indonesian currency of sample listed on the IDX; CFO is cash flow from operation; The p-value is in parantheses

In eq. 1 , the p-value of CSR expenditure is not statistically significant, implying that the result supports the charity hypothesis. This findings can be justified as follows. Firstly, the average CSR expenditure is in the form of social responsibility. This support Qiu, Shaukat and Tharyan (2016). Secondly, the corporate's goals to fulfill CSR are obligations and compliance with regulation No. 40/2007, among other regulation, intended solely to obtain "operating licenses" from stakeholders and the wider community (Hackston and Milne, 1996; Walden and Schwartz, 1997). Lastly, this study does not divide the corporate's CSR expenditure as Lys, Naughton and Wang (2015) into economic and non-economic performance aspects. This is caused by the fact that not all sample corporates in our research clearly stated the separation of their CSR expenditures.

Our study on corporate performance variables (ROA) draws interesting results. In the regression eq. 1, the results show that this current year's performance affects future performance. ROA itself describes the use of corporate assets and shows management effectiveness in managing investments. In this study, if the sample corporate has a profitable "track record" and has the commitment to 
social investment, the corporate will also be easier to reach customers who are willing to pay more for the green products produced (Tsai et al., 2012). According to Qiu, Shaukat and Tharyan (2016), corporates will be willing to enter into a commitment and openly express it only if they have a "way" to disclose it.

In eq. 2, the correlation between CSR expenditure with $\mathrm{CFO}$ variables is not statistically significant ( $p$-value is 0.755). Simply put, the average CSR expenditures made by the corporate do not relate to the corporate's cash flow. This finding, then, suggest that CSR expenditures incurred by corporates in Indonesia are aimed at philanthropy (Chapple and Moon, 2005) which are not directly related to corporate operations and is not even related to corporate performance (Lev, Petrovits and Radhakrishnan, 2010; Hong, Kubik and Scheinkman 2012; Nollet, Filis and Mitrokostas, 2016; Bose, Podder and Biswas, 2017).

\section{CONCLUSION}

Our results provide empirical evidence that corporate monetary expenditures in form of CSR by public corporates in Indonesia are more on actions aimed at charity without expecting anything in return and are not signals of the corporate's future performance. This result is in parallel with the evidence presented by Chapple and Moon (2005), Visser (2009), Ragodo (2009), Amos (2018). The finding of our study that corporate monetary expenditures in form of CSR are not related to corporate performance can be caused by the culture of the corporate's CSR in Indonesia not directed to improve the corporate performance. CSR activities in developing countries according to Visser (2009) are often associated with charity, for example through corporate social investment in the fields of education, health, sports development, the environment, and other community services. Ragodoo (2009) stated that most corporates have established procedures related to the allocation of funds for corporate social responsibility (CSR). This indicates the goodwill of the corporates that they are willing to help create a better social life of the society and indeed the corporate has the resources to do so. In addition, the active involvement of corporate management and community leaders in the corporate's CSR activities is equally an important factor.

This study did not succeed in providing evidence that CSR expenditure has an effect on future corporate performance. The explanation that we might provide is as follows: First, the samples in this study are only corporates with CSR expenditures data that we can obtain. Some of the corporates we observe actually incur expenditures related to CSR but the numbers are uncertain or do not clearly show the value of the money they spend. There are still many other corporates that we did not include into the sample because of the absence of CSR expenditures figures that we could use. Second, social problems in developing countries, including Indonesia, are unique. Visser (2009) and Saleh, Zulkifli and Muhamad (2011) for example, stated that CSR activities in developing countries 
are only carried out by widely known national and multinational corporates. That means, even though a corporation is financially able to perform CSR activities in form of CSR monetary expenditures but does not face the risk of being monitored by the public, then CSR monetary expenditures will be revealed differently compared to similar corporates known to the public. In addition, CSR activities in developing countries according to Visser (2009) are not formalized and are not institutionalized as in developed countries.

Furthermore, the pattern and behavior of CSR in developing countries, which are different from developed countries, are importantly required to be studied focuses particularly on developing countries. According to Amos (2018), this is due to the conventional approach to CSR in developing countries currently rooted strongly in CSR behavior in developed countries which may not be related in the context and the actual situation faced by developing countries. Lev, Petrovits and Radhakrishnan (2010), Hong, Kubik and Scheinkman (2012), Lys, Naughton and Wang (2015) and Nollet, Filis and Mitrokostas (2016), among others, use samples from developed countries. Their studies indicate that CSR expenditures is a signal of future companies' performance and shares values.

\section{Suggestion for Further Researchers}

Researches that are interested in analyzing the issue of CSR expenditures within corporate performance in the future should consider several important points. Researches on CSR expenditures in the future should be able to ensure the samples actually perform CSR expenditures that are oriented towards corporate performance or, at least, future researchers should consider separating CSR expenditures related to economic performance (signal) and non-economic performance (charity). Visser (2009) claims that the lack of comparative studies related to the nature, type, and extent of disclosure of CSR activities between developing countries and developed countries can be a consideration for researchers regarding CSR in the future. Furthermore, future studies can also be done by comparing CSR expenditures to performance among developing countries that fall into the high profile category.

\section{REFERENCES}

Aly, D., El-Halaby, S. and Hussainey, K., 2018. Tone disclosure and financial performance: evidence from Egypt. Accounting Research Journal, [e-journal] 31(1), pp.63-74. 10.1108/ARJ-09-2016-0123.

Amos, G.J., 2018. Researching corporate social responsibility in developingcountries context: A systematic review of the literature. International Journal of Law and Management, [e-journal] 60(2,) pp.284-310. 10.1108/IJLMA-04-20170093.

Bénabou, R. and Tirole, J., 2010. Individual and corporate social responsibility. Economica, [e-journal] 77(305), pp.1-19. 10.1111/j.1468-0335.2009.00843.x. 
Beyer, A., Cohen, D.A., Lys, T.Z. and Walther, B.R., 2010. The Financial Reporting Environment: Review of the Recent Literature. Journal of Accounting and Economics, [e-journal] 50(2-3), pp.296-343. 10.1016/j.jacceco.2010.10.003.

Bose, S., Podder, J. and Biswas, K., 2017. Philanthropic giving, market-based performance and institutional ownership: Evidence from an emerging economy. The British Accounting Review, [e-journal] 49(4), pp.429-444. 10.1016/j.bar.2016.11.001.

Bowen, H.R., 1953. Social responsibilities of the businessman. New York: Harper.

Brammer, S., Brooks, Ch. and Pavelin, S., 2006. Corporate Social Performance and Stock Returns: UK Evidence from Disaggregate Measures. Financial Management, [e-journal] 35(3), pp.97-116.

Brammer, S. and Millington, A., 2008. Does it pay to be different? An analysis of the relationship between corporate social and financial performance. Strategic Management Journal, [e-journal] 29(12), pp.1325-1343. 10.1002/smj.714.

Cai, Y., Pan, C.H. and Statman, M., 2016. Why do countries matter so much in corporate social performance?. Journal of Corporate Finance, [e-journal] 41, pp.591-609. 10.1016/j.jcorpfin.2016.09.004.

Campbell, J.L., 2007. Why Would Corporations Behave in Socially Responsible Ways? An Institutional Theory of Corporate Social Responsibility. The Academy of Management Review, 32(3), pp.946-967.

Carroll, A.B, 2004. Managing ethically with global stakeholders: a present and future challenge. Academy of Management Executive, 18(2), pp.114-120.

Committee Encouraging Corporate Philanthropy (CECP), 2008. Giving in Numbers 2008. [pdf] New York, USA: CECP. Available at: $<$ http://www.corporatephilanthropy.org/pdfs/benchmarkingreports/GivinginNumbers2008.pdf> [Accessed 10 August 2019].

Dainelli, F., Bini, L. and Giunta, F., 2013. Signaling strategies in annual reports: Evidence from the disclosure of performance indicators. Advances in Accounting. [e-journal] 29(2), pp.267-277. 10.1016/j.adiac.2013.09.003.

Darmadi, S., 2013. Board members' education and firm performance: evidence from a developing economy. International Journal of Commerce and Management, [e-journal] 23(2), pp.113-135. 10.1108/10569211311324911.

El Ghoul, S., Guedhami, O., Kwok, Ch.C.Y. and Mishra, D.R., 2011. Does corporate social responsibility affect the cost of capital?. Journal of Banking and Finance, [e-journal] 35(9), pp.2388-2406. 10.1016/j.jbankfin.2011.02.007.

Esteban-Sanchez, P., De la Cuesta-Gonzalez, M. and Paredes-Gazquez, J.D., 2017. Corporate social performance and its relation with corporate financial performance: International evidence in the banking industry. Journal of Cleaner Production, [e-journal] 162, pp.1102-1110. 10.1016/j.jclepro.2017.06.127. 
Fombrun, C.J., 2005. Building corporate reputation through CSR initiatives: evolving standards. Corporate Reputation Review, [e-journal] 8, pp.7-11. 10.1057/palgrave.crr.1540235.

Friedman, M., 1970. The social responsibility of business is to increase its profits. The New York Times Magazine, 13 September.

Galaskiewicz, J., 1991. Making corporate actors accountable. Institution-building in Minneapolis-St. Paul. In: P.J. DiMaggio and W.W. Powell, eds. 1991. The New Institutionalism in Organizational Analysis. Chicago, Il: The University of Chicago Press. Chapter 12.

Griffin, J.J. and Prakash, A., 2014. Corporate Responsibility: Initiatives and Mechanisms. Business and Society, [e-journal] 53(4), pp.465-482. 10.1177/0007650313478975.

Hackston, D. and Milne, M., 1996. Some determinants of social and environmental disclosures in New Zealand. Journal Accounting Auditing and Accountability, [e-journal] 9(1), pp.77-108. 10.1108/09513579610109987.

Healy, P.M. and Palepu, K.G., 2000. Information asymmetry, corporate disclosure, and the capital markets: A review of the empirical disclosure literature. Journal of Accounting and Economics, [e-journal] 31, pp.405-440.

Hillman, A.J. and Keim, G.D., 2001. Shareholder value, stake- holder management, and social issues: what's the bottom line?. Strategic Management Journal, 22(2), pp.125-139.

Hong, H., Kubik, J. and Scheinkman, J., 2012. Financial Constraints on Corporate Goodness. [online] Available at SSRN: $<$ https://ssrn.com/abstract=1734164> [Accessed 19 November 2019].

Hopwood, A.G., 2009. Accounting and the environment. Accounting, Organizations and Society, [e-journal] 34(3-4), pp.433-439. 10.1016/j.aos.2009.03.002.

Humphrey, J.E., Lee, D.D. and Shen, Y., 2012. Does it cost to be sustainable?. Journal of Corporate Finance, 18(3), pp.626-639.

Chapple, W. and Moon, J., 2005. Corporate Social Responsibility (CSR) in Asia A Seven-Country Study of CSR Web Site Reporting. Bussines and Society, [ejournal] 44(4), pp.415-441. 10.1177/0007650305281658.

Chen, L., Feldmann, A. and Tang, O., 2015. The relationship between disclosures of corporate social performance and financial performance: evidences from GRI reports in manufacturing industry. International Journal of Production Economics, 170(Part B), pp.445-456. 10.1016/j.ijpe.2015.04.004.

Ching, H.Y. and Gerab, F., 2017. Sustainability reports in Brazil through the lens of signaling, legitimacy and stakeholder theories. Social Responsibility Journal, [e-journal] 13(1), pp.95-110. 10.1108/SRJ-10-2015-0147. 
Choi, J. and Wang, H., 2007. The Promise of a Managerial Values Approach to Corporate Philanthropy. Journal of Business Ethics, [e-journal] 75(4), pp.345359. 10.1007/s10551-006-9257-4.

Christensen, H.B., Floyd, E., Liu, L.Y. and Maffett, M., 2017. The real effects of mandated information on social responsibility in financial reports: Evidence from mine-safety records. Journal of Accounting and Economics, [e-journal] 64(2-3), pp.284-304. 10.1016/j.jacceco.2017.08.001.

John, K. and Williams, J., 1985. Dividends, dilution, and taxes: a signaling equilibrium. Journal of Finance, 40(4), pp.1053-1070.

Kreander, N., Beattie, V. and McPhail, K., 2009. Putting our money where their mouth is: Alignment of charitable aims with charity investment setensions in policy and practice. The British Accounting Review, 41(3), pp.154-168.

Law of the Republic of Indonesia number 40 of 2007 concerning limited liability companies.

Lech, A., 2013. Corporate Social Responsibility and Financial Performance Theoretical and Empirical Aspects. Comparative Economic Research. Central and Eastern Europe, [e-journal] 16(3), pp.49-62. 10.2478/cer-2013-0018.

Lev, B., Petrovits, Ch. and Radhakrishnan, S., 2010. Is Doing Good For You? How Corporate Charitable Contributions Enhance Revenue Growth. Strategic Management Journal, [e-journal] 31(2), pp.182-200. 10.1002/smj.810.

Lys, T., Naughton, J. and Wang, C., 2015. Signaling through corporate accountability reporting. Journal of Accounting and Economics, [e-journal] 60(1), pp.56-72. 10.1016/j.jacceco.2015.03.001.

Mahoney, S.L., Thorne, L., Cecil, L. and LaGore, W., 2013. A research note on standalone corporate social responsibility reports: Signaling or greenwashing?. Critical Perspectives on Accounting, [e-journal] 24(4-5), pp.350-359. 10.1016/j.cpa.2012.09.008.

Miller, M. and Rock, K., 1985. Dividend policy under asymmetric information. Journal of Finance, [e-journal] 40(4), pp.1031-1051. 10.1111/j.15406261.1985.tb02362.x.

Navarro, P., 1988. Why Do Corporations Give to Charity?. The Journal of Business, 61(1), pp.65-93.

Nollet, J., Filis, G. and Mitrokostas, E., 2016. Corporate social responsibility and financial performance: A non-linear and disaggregated approach. Economic Modelling, [e-journal] 52(Part B), pp.400-407. 10.1016/j.econmod.2015.09.019.

Qiu, Y., Shaukat, A. and Tharyan, R., 2016. Environmental and social disclosures: Link with corporate financial performance. The British Accounting Review, [e-journal] 48(1), pp.102-116. 10.1016/j.bar.2014.10.007. 
Ragodoo, N.J.F., 2009. CSR as a tool to fight against poverty: the case of Mauritius. Social Responsibility Journal, [e-journal] 5(1), pp.19-33. 10.1108/17471110910939971.

Rhou, Y., Singal, M. and Koh, Y., 2016. CSR and financial performance: The role of CSR awareness In the Restaurant industry. Journal of Hospitality Management, [e-journal] 57, pp.30-39. 10.1016/j.ijhm.2016.05.007.

Saleh, M., Zulkifli, N. and Muhamad, R., 2011. Looking for evidence of the relationship between corporate social responsibility and corporate financial performance in an emerging market. Asia-Pacific Journal of Business Administration, [e-journal] 3(2), pp.165-190. 10.1108/17574321111169849.

Servaes, H. and Tamayo, A., 2013. The impact of corporate social responsibility on firm value: the role of customer awareness. Management Science, [e-journal] 59(5), pp.1045-1061. 10.1287/mnsc.1120.1630.

Supriyati and Tjahjadi, B., 2017. Corporate Social Responsibility and Financial Performance: Stakeholder Theory vs Good Management Theory. International Journal of Economic Research, 14(16), pp.235-244.

Testa, M., D'Amato, A., 2017. Corporate environmental responsibility and financial performance: does bidirectional causality work? Empirical evidence from the manufacturing industry. Social Responsibility Journal, [e-journal] 13(2), pp.221-234. 10.1108/SRJ-02-2016-0031.

Tsai, M.-T., Chuang, L.-M., Chao, S.-T. and Chang, H.-P., 2012. The effects assessment of firm environmental strategy and customer environmental conscious on green product development. Environmental Monitoring and Assessment, [e-journal] 184(7), pp.4435-4447. 10.1007/s10661-011-2275-4.

Visser, W., 2009. Corporate Social Responsibility in Developing Countries. In: A. Crane, D. Matten, A. McWilliams, J. Moon, and D.S. Siegel, eds. 2009. The Oxford Handbook of Corporate Social Responsibility. King's Lynn, Norfolk: Oxford University Press.

Walden, W.D. and Schwartz, B.N., 1997. Environmental disclosures and public policy pressure. Journal of Accounting and Public Policy, 16(2), pp.125-154.

Wang, H. and Qian, C., 2011. Corporate philanthropy and corporate financial performance: The roles of stakeholder response and political access. Academy of Management Journal, [e-journal] 54(6), pp.1159-1181. 10.5465/amj.2009.0548.

Wang, H., Tong, L., Takeuchi, R. and George, G., 2016. Corporate Social Responsibility: An Overview And New Research Direction Thematic Issue on Corporate Social Responsibility [From The Editors]. Academy of Management Journal, [e-journal] 56(2), pp.534-544. 10.5465/amj.2016.5001.

Wang, Z. and Sarkis, J., 2017. Corporate Social Responsibilities Governance Outcome and Financial Performance. Journal of Cleaner Production, [e-journal] 162, pp.1607-1616. 10.1016/j.jclepro.2017.06.142. 
Weber, M., 2008. The business case for corporate social responsibility: A company-level measurement approach for CSR. European Management Journal, [e-journal] 26, pp.247-261. 10.1016/j.emj.2008.01.006.

Zhang, J., 2016. Does Corporate Social Responsibility Affect Financial Performance of Listed Manufacturing Firms in Germany?. University of Twente.

\section{ABOUT AUTHORS}

Erna Widiastuty - student at Accounting Doctoral Program Faculty of Economics and Business Universitas Airlangga Surabaya East Java Indonesia and Lecturer at Department of Accounting Faculty of Economics Andalas University, Padang Indonesia. Author's ORCID: 0000-0002-6266-1459.

Noorlailie Soewarno - lecturer at Faculty of Economics and Business, Universitas Airlangga, Surabaya, East Java, Indonesia. E-mail: noorlailies@feb.unair.ac.id, Author's ORCID: 0000-0003-2134-2125.

Conflicts of Interest: The authors declare no conflict of interest.

(C) 2019 by the authors. Submitted for possible open access publication under the terms and conditions of the Creative Commons Attribution (CC-BY) license (http://creativecommons.org/licenses/by/4.0/). 